\title{
River-dike-floodplain system interactions and temporal dynamics for large-scale flood risk assessment
}

\author{
Mostafa Farrag ${ }^{1}$, Sergiy Vorogushyn ${ }^{1}$, Dung Viet Nguyen ${ }^{1}$, Karin de Bruijn $^{2}$ and Bruno Merz ${ }^{1,3}$ \\ ${ }^{1}$ GFZ German Research Centre for Geosciences, Section Hydrology, Potsdam, Germany. \\ ${ }^{2}$ Deltares, Department of Flood Risk Management, Delft, The Netherlands \\ ${ }^{3}$ University of Potsdam, Institute for Environmental Sciences and Geography, Potsdam Germany
}

\begin{abstract}
In a complex network river, hydrodynamic interactions - changes of hydrodynamic characteristics downstream due to upstream effects - play an important role when determining flood hazard and risk. The correct representation of the hydrodynamic interactions is very important for flood modelling and improves our ability to simulate flood extent and inundation depths. The aggregate effect of these interactions on a large-scale catchment highly affects the overall volume of water inundating the floodplain. In this study, the Derived Flood Risk Assessment "DFRA" approach is applied in the Rhine catchment based on the Regional Flood Model (RFM), where two versions of the Regional Inundation Model (RIM) are compared. The two versions are characterized by different routing approaches (piece-wise and continuous routing) and by different cross-section estimation methods. Results show a significant difference between the inundation patterns resulting from the two routing approaches. The continuous routing approach results in less overtopping downstream, while almost no difference is simulated in the upstream part of the network.
\end{abstract}

\section{Introduction}

Risk information is essential for decision making of flood risk management. For large scale river basins, risk pattern changes within the basin due to changes in the flood risk drivers. Therefore modelling the interactions between upstream and downstream sub-areas need to be considered.

Recent developments used in large-scale hydrodynamic models for flood risk assessment rely on different approaches to represent all physical processes considering the limited computational power and input data (De Paiva et al., 2013). The hydrodynamics of the river is usually described by the continuity and the SaintVenant Momentum Equations (Coe et al., 2008). For the simulation of floodplain flow, often storage models are used. Such storage cell model was first proposed by (Dino Zanobetti, 1970) and considers storage areas in a grid where the mass balance is updated each time step considering the inflow and outflow from each cell. Fluxes between cells areas are calculated using uniform flow formulas. The main advantage of the storage cell formulation is the relative simple calculation of fluxes (Bates et al., 2010).

Simulations with large time steps using storage cell models develop chequerboard type instability, which is an oscillation of the water depth between neighbouring cells (Cunge et al., 1980). Some models use a flow limiter

a Corresponding author: mostafa.farrag $@$ gfz-potsdam.de

DOI 10.3311/FLOODRisk2020.9.11 approach to prevent these oscillations, and others use adaptive time-stepping following the Courant-FriedrichsLewy criterion (Hunter et al., 2005).

In the research described in this paper, the Derived Flood Risk Analysis "DFRA" approach is applied, which also contains the cell-storage approach. The DFRA is an approach to estimate flood risk based on a chain of models for continuous simulation of all processes to account for the spatial heterogeneity of precipitation patterns, discharge, inundation, and damage (Falter et al., 2015). This DFRA approach was applied for different catchments in Germany (Falter et al., 2015; Metin et al., 2019), using the Regional Flood Model (RFM) (Falter et al., 2015). The RFM consists of a weather generator, a rainfall-runoff model, a regional inundation model (RIM), and flood damage estimation model. RIM consists of a $1 \mathrm{D}$ river routing model coupled with a $2 \mathrm{D}$ storage cell hinterland inundation model based on the inertia formulation of the momentum equation proposed by Bates et al. (2010). The latter model is implemented in CUDA Fortran and run in GPU environment.

The current coupling between the rainfall-runoff model and RIM depends on a piece-wise routing approach. The piece-wise routing does not transfer the effect of the flood waves from upstream to downstream in the right way, as the model does not transfer the appropriate volume of water between sub basins after taking out the volume of 
water that overtops the dikes. To test the relevance of that interaction between upstream and downstream subareas, an improvement is made to consider this system behaviour with a continuous routing approach. The continuous routing transfers the appropriate volume from sub-basin to another, considering the interaction between subareas.

In this paper, we address the hydrodynamic interactions between the river network and the floodplain by comparing two approaches for 1D-2D coupled simulation. The first one (piece-wise approach) routes the flow above the 2-year return period threshold piece-wise within each sub-basin. The second method considers hydraulic geometry $(\mathrm{HG})$ relationships to derive the bankfull depth and routes the flow continuously through the entire river network. Whereas the first method considers hydrodynamic interactions only within a single sub-basin, the second method transfers the effect through the whole river network.

\section{Methodology}

The Regional Flood Risk Model (RFM) (Figure 1) is developed at GFZ and includes a weather generator (Hundecha et al., 2009), the SWIM hydrological model (Krysanova et al., 1998), the Regional Inundation Model (RIM) and the damage assessment model FLEMO (Falter et al., 2016).

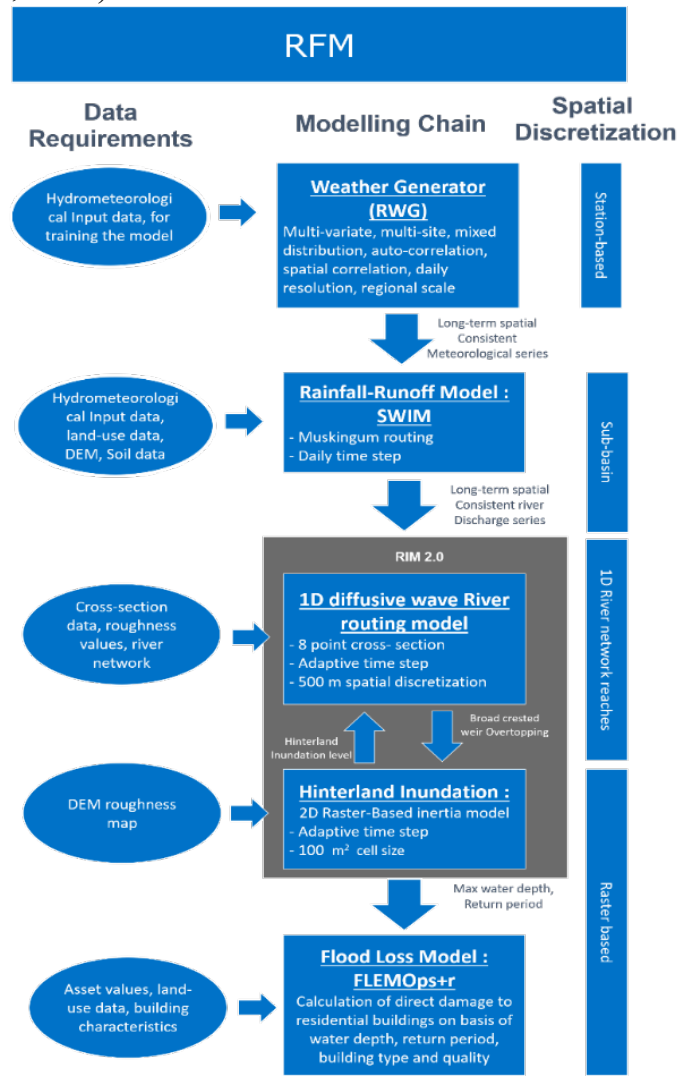

Figure 1: Regional Flood Risk Model (RFM)

SWIM hydrological model (Krysanova et al., 1998) is a conceptual distributed rainfall-runoff model simulating daily runoff on a sub-basin level and routing it using a ROTO hydrological routing method (Arnold, Williams, \& Maidment, 1995).
The Regional Inundation Model (RIM1.0) comprises a $1 \mathrm{D}$ river routing model that solves diffusive wave approximation of shallow water equations (Eq.Error! Reference source not found. \& Error! Reference source not found. ) explicitly with finite difference numerical scheme.

$$
\begin{aligned}
& \frac{\partial Q}{\partial t}+\frac{\partial^{2}}{\partial x^{2}}\left(\frac{Q^{2}}{A}\right)+g A \frac{\partial h}{\partial x}-g A\left(S_{o}-S_{f}\right)=0 \\
& \frac{\partial \mathrm{Q}}{\partial \mathrm{x}}+\frac{\partial \mathrm{A}}{\partial \mathrm{t}}=0
\end{aligned}
$$

Where $Q$ is flow rate $\left(\mathrm{m}^{3} / \mathrm{s}\right), \mathrm{A}$ is area $\left(\mathrm{m}^{2}\right), \mathrm{g}$ is acceleration $\left(\mathrm{m} / \mathrm{s}^{2}\right), s_{o}$ is slope $\left(\mathrm{m}^{-1}\right), s_{f}$ is friction slope $\left(\mathrm{m}^{-1}\right), \mathrm{t}$ is time $(\mathrm{sec})$ and $\mathrm{x}$ is distance $(\mathrm{m})$.

The second component of RIM is the $2 \mathrm{D}$ raster-based hinterland inundation model, which uses the inertia formulation of the shallow water equation to calculate the discharge per unit width $(\mathrm{q})$ in each direction (Eqn.3). The change in water depth at each cell is computed by the continuity equation (Eqn.4).

$$
\begin{aligned}
& \mathrm{q}_{\mathrm{t}+\Delta \mathrm{t}}=\frac{\mathrm{q}_{\mathrm{t}}+\mathrm{gh}_{\mathrm{flow}} \Delta \mathrm{t} \mathrm{S}_{\mathrm{f}}}{\left(1+\mathrm{gh}_{\mathrm{flow}} \Delta \mathrm{t}+\mathrm{n}^{2}\left|\mathrm{q}_{\mathrm{t}}\right| / \mathrm{h}_{\mathrm{flow}}{ }^{\frac{10}{3}}\right)} \\
& \frac{\partial \mathrm{h}^{\mathrm{i}, \mathrm{j}}}{\partial \mathrm{t}}=\frac{\mathrm{q}_{\mathrm{x}}^{\mathrm{i}-1, \mathrm{j}}-\mathrm{q}_{\mathrm{x}}^{\mathrm{i}, \mathrm{j}}+\mathrm{q}_{\mathrm{y}}^{\mathrm{i}-1, \mathrm{j}}-\mathrm{q}_{\mathrm{y}}^{\mathrm{i}, \mathrm{j}}}{\Delta \mathrm{x}}
\end{aligned}
$$

where $\Delta \mathrm{t}$ is the time step, $\mathrm{n}$ is Manning's roughness coefficient, $h_{\text {flow }}$ is the water depth.

The $2 \mathrm{D}$ model is activated when water levels in the river exceed the dikes crest height, and overtopping flow calculated with broad crested weir equation enters the floodplain. The coupling between the 1D and 2D models is one way, and no return flow from the floodplain to the river is considered.

The 2D code is written in a high-performance computing environment using CUDA Fortran to utilize the maximum capability of the parallelized NIVIDIA Graphical Processor Units (GPU).

RIM1.0 uses adaptive time stepping. The CourantFriedrichs-Lewy stability condition is applied to determine the adaptive time step (Eqn.5).

$$
\Delta \mathrm{t}_{\max }=\alpha \frac{\Delta \mathrm{x}}{\sqrt{\text { gh }_{\text {flow }}}}
$$

where the value of $\alpha$ ranges from 0.2 to 0.7 based on (Bates et al., 2010).

RIM1.0 1D river routing is driven by discharge upstream boundary conditions obtained by the SWIM model for each sub-basin along with the river network (piece-wise routing) The SWIM routing method does not calculate water levels. Thus the upstream boundary condition does not consider any overtopping that might take place at upstream sub-basins.

Cross-sections used in RIM1.0 are derived from the $10 * 10 \mathrm{~m}^{2} \mathrm{DEM}$ and simplified to six points trapezoidalshape cross-sections. The derived cross-sections represent the overbank area, whereas the bankfull area is statistically estimated to be equivalent to the 2-year return period discharge HQ2. The value of HQ2 is cut off the upstream boundary condition before the $1 \mathrm{D}$ routing model is initiated. The boundary condition at each piece of the river network is updated based on SWIM output for each subbasin.

The newly developed version RIM2.0 overcomes the shortcomings of the RIM1.0, which does not consider the upstream overtopping and consequently likely 
overestimates discharge and inundation at downstream parts of the river network. RIM2.0 uses a continuous routing method where the routed hydrograph by RIM from the upstream sub-basins is used as an upstream boundary condition for the next downstream sub-basin in the river network.

Cross-sections used in RIM2.0 uses the six-point simplified overbank cross-sections in addition to hydraulic geometry $(\mathrm{HG})$ relationships (Eqn.6 \& 7) to estimate the bankfull depth $\left(\mathrm{d}_{\mathrm{BF}}\right)$ and assumes the bankfull area is rectangular with the width $\left(\mathrm{W}_{\mathrm{BF}}\right)$ obtained from the DEM. $d_{B F}=a H Q_{2}{ }^{b}$

$W_{B F}=c H Q_{2}^{d}$

The hydraulic geometry relationships relate the geometrical properties of the cross-section to catchment and channel and flow characteristics with a power function. We use the obtained function in Eq. 8 to get the cross-section at all network locations. HQ2 can be used as a representative of the bankfull area (Rawlins, 1994). A relation between HQ2 and drainage area at gauge locations. This relationship was used to estimate HQ2 at other points in the river network. After estimating parameters, a, b, c, and d, the combination of Eqn. 6 \&7 resulting in Eq. 8 delivered the best fit to the surveyed cross-sections. Bankfull depth was then estimated at all network locations using Eq. 8

$d_{B F}=a\left(\frac{W_{B F}}{c}\right)^{b / d}$

\subsection{Calibration}

The obtained initial bankfull depth was further calibrated in the range $\mathrm{d}_{\mathrm{BF}} \pm 0.5(\mathrm{~m})$ to meet the discharge hydrographs of the SWIM hydrological routing since the performance of RIM is strongly dominated by the performance of the hydrological input from SWIM.

The following criterion was used to assess the performance of RIM.

$N S E_{\text {Modeified }}=1-\frac{\sum_{t} W_{t}(\text { Qobs }-Q \operatorname{sim})^{2}}{\sum_{t} W_{t}(\text { Qobs }-Q \text { Quvg })^{2}}$

where $Q$ obs is the observed flow rate, $Q \operatorname{sim}$ is the simulated flow rate, and Qavg is the average of observed flow. $W_{t}$ is a weight that differs each time step based on the observed flow, $\mathrm{W}_{\mathrm{t}}$ equals one was used to get the values of the NSE.

\section{Study area and data}

Rhine catchment has a total area of $185,260 \mathrm{~km}^{2}$ and is one of the largest river basins in Europe

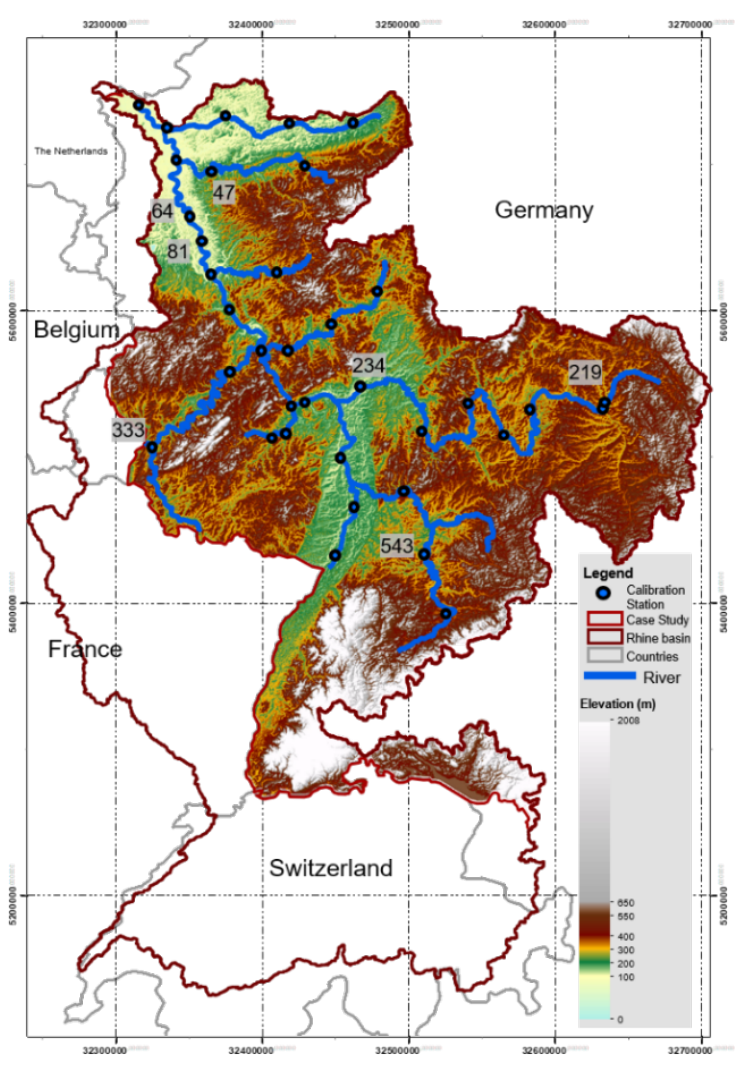

Figure 2), with10.5 million inhabitants living in floodprone areas

(International Commission for the Protection of the Rhine (ICPR), 2013).

$10 * 10 \mathrm{~m}^{2}$ digital elevation model DEM was used to extract the overbank area of the cross-section for the German part of the river network represented in RFM (Figure 2). The resampled $100 * 100 \mathrm{~m}^{2} \mathrm{DEM}$ was used to represent the floodplain in the 2D simulation. A few hundreds of surveyed cross-sections on the main channel, Mosel and Neckar tributaries, were available from the Federal Institute of Hydrology (BfG) and used for validation of hydraulic geometry relationships. Rainfall and discharge data were provided by the Global Runoff Data Centre (GRDC) to run and validated the SWIM model.

\section{Results and Discussions}

The bankfull depth was derived from the hydraulic geometry relations using the form in Eqn.8. The best fit of the estimated and measured bankfull depth resulted in Eqn. 10 with an overall mean absolute error of 1.019 and mean bias error of -0.1236 .

$d_{B F}=0.6354\left(\frac{W_{B F}}{0.7093}\right)^{0.3961}$

\subsection{Performance of SWIM and RIM}

The performance of both RIM1.0 and RIM2.0 is further compared in terms of overtopping discharge and hydrograph simulation at selected locations.

When water levels exceed dike levels, overtopping discharge is estimated empirically based on a broad crested 
weir equation with assumed overtopping width of $10 \mathrm{~m}$. In order to compare the results of RIM with the observed discharge and water levels, extensive information on the dike levels and the overtopping process itself (location and duration) is needed. However, for such a large-scale catchment, this required information is not available all over the basin. Therefore, in this study, we compare the simulated hydrographs by RIM with the results of the SWIM model, as the main goal is to investigate the effect of the new changes implemented on RIM2.0.

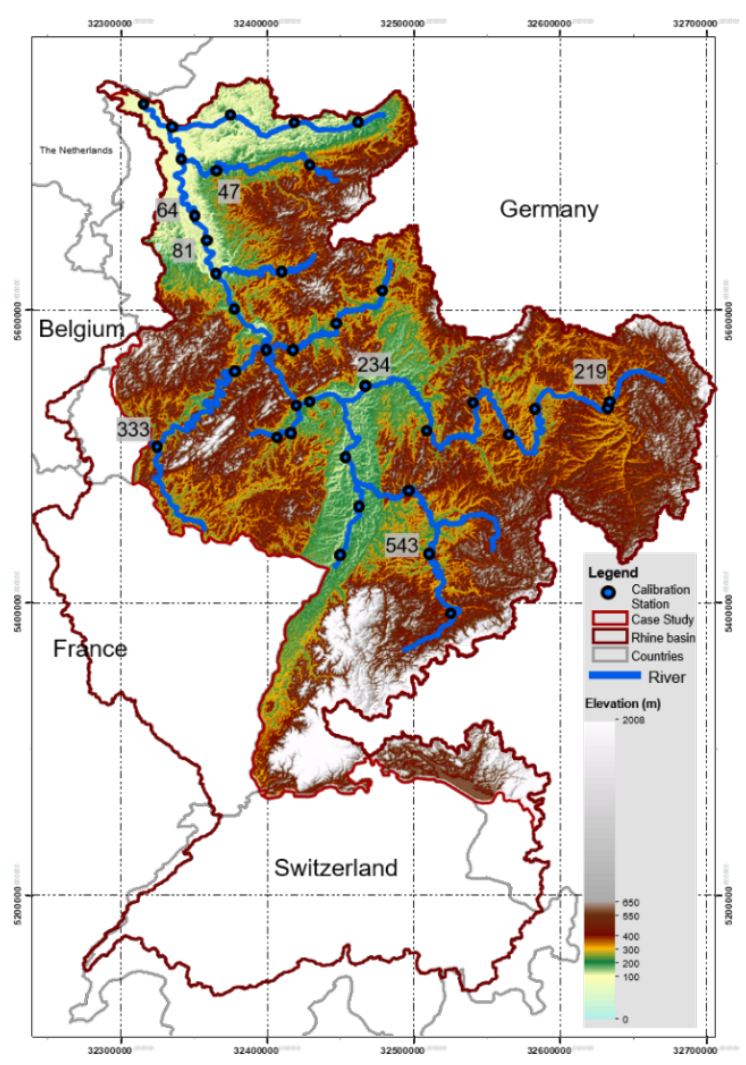

Figure 2: Rhine basin and calibration stations

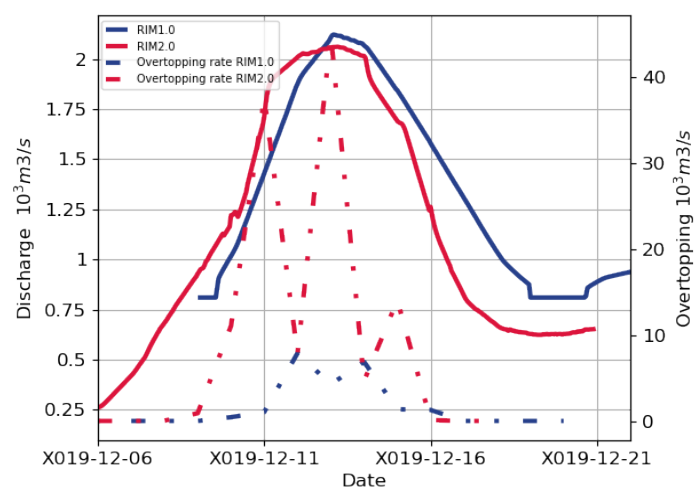

Figure 3: Effect of different routing approaches at upstream locations (left panel) (sub-basin 234) and downstream location (right panel) (sub-basin 64)

\subsection{Hydrodynamic interactions}

When overtopping flow occurs in the upstream subbasins, the hydrograph is attenuated further downstream. As a result, less inundation can be expected in the

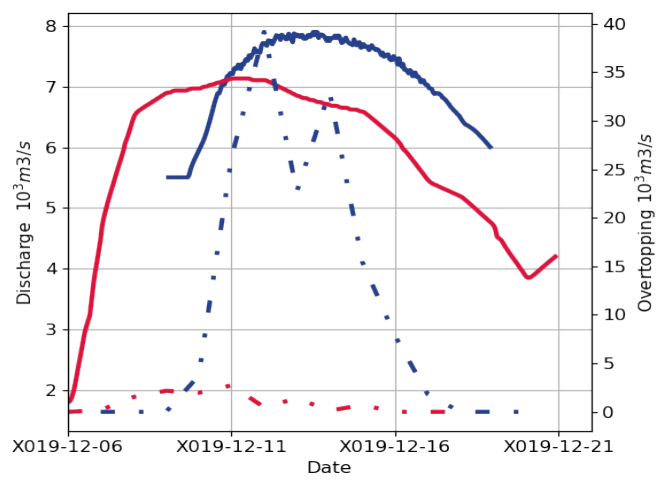

The overall performance of both RIM models is good except at gauging station 333 in the Mosel catchment. The reason is the poor performance of SWIM at this branch of the Rhine. For all other gauges, the performance of RIM1.0 ranges between 0.6 and 0.94 for Nash-Sutcliffe and between 0.65 and 0.95 for modified Nash-Sutcliffe efficiency (Error! Reference source not found.). RIM2.0 outperformed RIM1.0 at most gauges with a Nash-Sutcliff ranges between 0.81 and 0.89 and modified Nash-Sutcliffe between 0.8 and 0.97 .

Table 1: Comparison between RIM, SWIM and observed discharge data in terms of NSE and modified NSE

\begin{tabular}{|c|c|c|c|c|}
\hline \multirow{2}{*}{ Station } & \multicolumn{2}{|c|}{47} & \multicolumn{2}{c|}{543} \\
\cline { 2 - 5 } & NSE & NSE(M) & NSE & NSE(M) \\
\hline RIM2.0-SWIM & 0.89 & 0.9 & 0.87 & 0.87 \\
\hline RIM1.0-SWIM & 0.6 & 0.65 & 0.71 & 0.78 \\
\hline SWIM-Observed & 0.64 & 0.74 & 0.82 & 0.86 \\
\hline \multirow{2}{*}{ Station } & \multicolumn{2}{|c|}{219} & \multicolumn{2}{|c|}{333} \\
\cline { 2 - 5 } & NSE & NSE(M) & NSE & NSE(M) \\
\hline RIM2.0-SWIM & 0.81 & 0.83 & 0.96 & 0.97 \\
\hline RIM1.0-SWIM & 0.6 & 0.65 & 0.56 & 0.73 \\
\hline SWIM-Observed & 0.61 & 0.82 & 0.16 & 0.16 \\
\hline \multirow{2}{*}{ Station } & \multicolumn{2}{|c|}{81} & \multicolumn{2}{|c|}{42} \\
\cline { 2 - 5 } & NSE & NSE(M) & NSE & NSE(M) \\
\hline RIM2.0-SWIM & 0.82 & 0.82 & 0.81 & 0.8 \\
\hline RIM1.0-SWIM & 0.94 & 0.95 & 0.94 & 0.95 \\
\hline SWIM-Observed & 0.75 & 0.75 & 0.75 & 0.76 \\
\hline
\end{tabular}

downstream areas. The newly implemented continuous routing approach in RIM2.0 considers hydrodynamic interactions between sub-basins in the entire rivernetwork, while the piece-wise routing in RIM1.0 does so only within each single sub-basin. Accumulation of the 
overtopping is more likely to appear at the downstream location. As a consequence, no significant difference in hydrographs from both RIM1.0 and RIM2.0 can be noticed as upstream parts of the catchments (see Figure 3 and

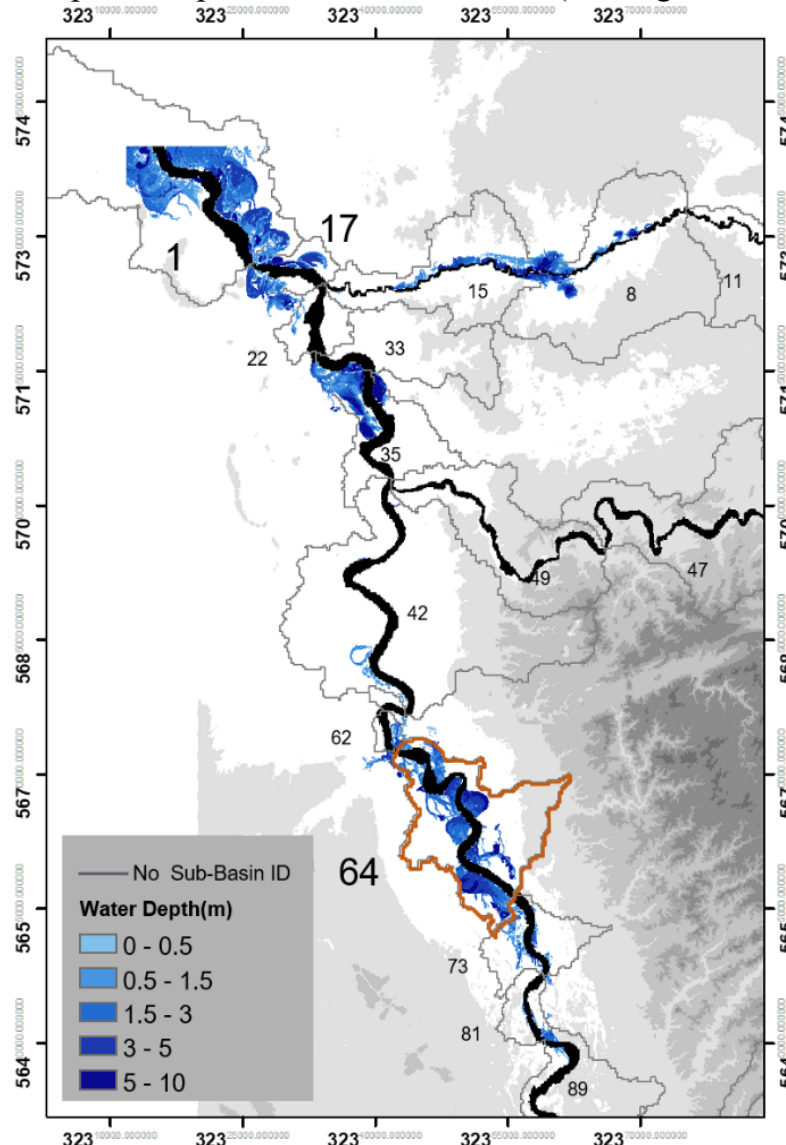

Figure 5 sub-basin 234). As a result, the difference in the inundation areas from both models is very small.

Different behaviour is expected at the downstream subbasins of the catchment where a lot of overtopping occurs. RIM2.0 hydrograph is much more attenuated than RIM1.0 (Figure 3, sub-basin-64), and the overtopping volume, inundated areas, and inundation depths are higher in RIM1.0 compared to RIM2.0. (Error! Reference source not found. and 5).
The effect of the routing approach can also be noticed in
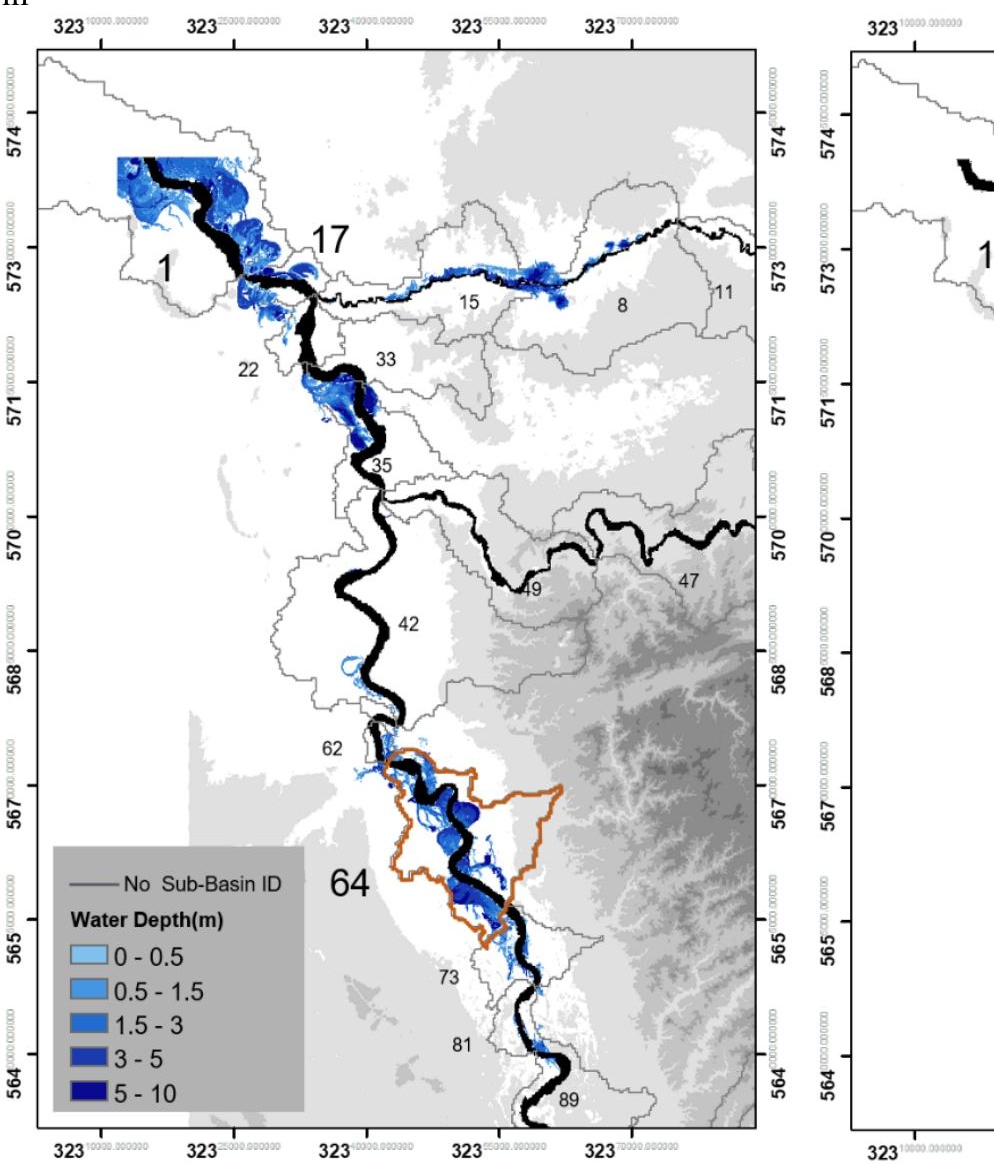

Figure 5 as the difference in the inundation area for sub-basin-234 located at the upstream part of the river network is very small. The difference in the inundation area between both models for sub-basin 64, which locates at the main river, is considerably larger.

the difference between RIM1.0 and RIM2.0 in crosssection estimating methods result in underestimation of the capacity of the cross-sections in RIM2.0 which in return 


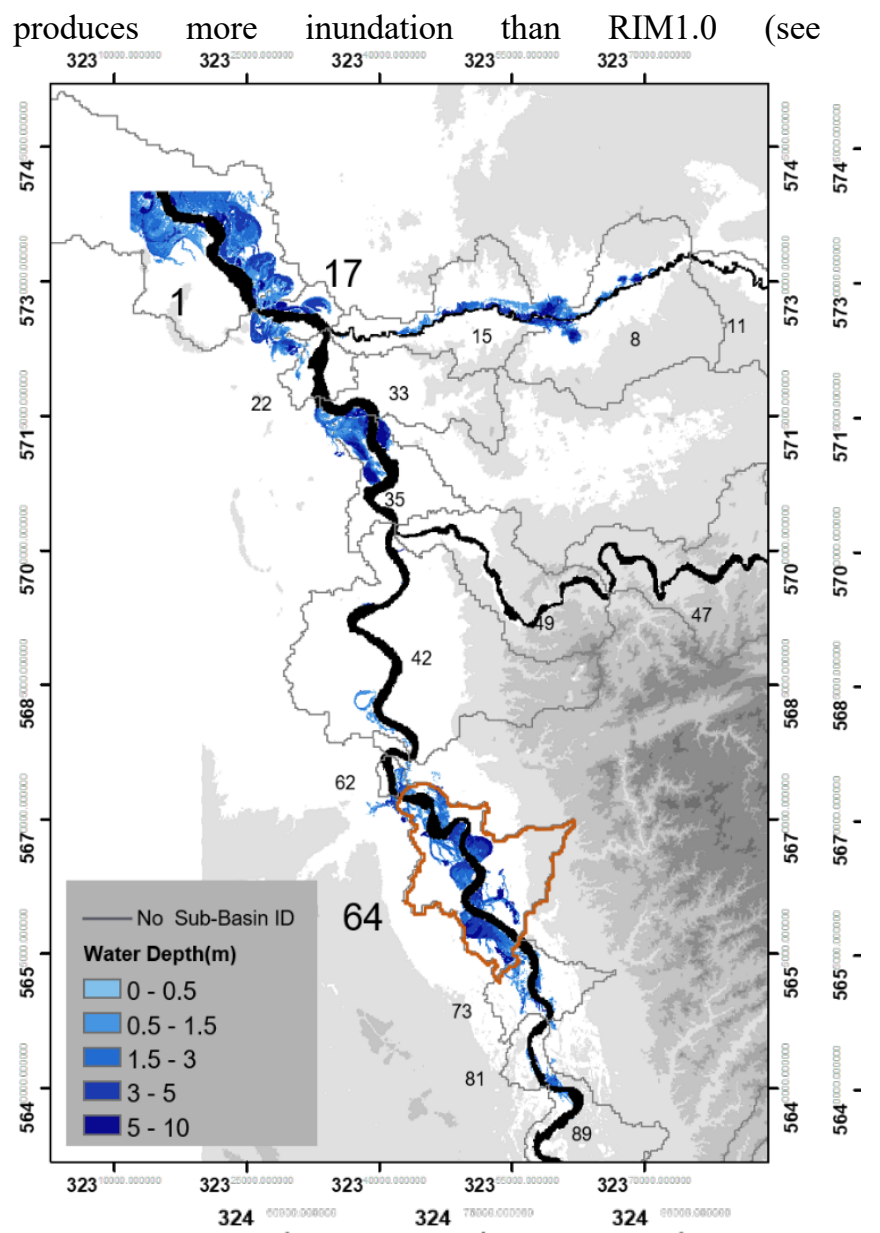

Figure 5 sub-basin 8).

Due to the continuous routing considered in RIM2.0, it was noticed that always events start 1day earlier than RIM1.0, where the 1D routing model only starts to work when discharge exceeds the HQ2 value. The model starts from dry initial conditions, which is the reason RIM1.0 takes the first time step as a warmup.

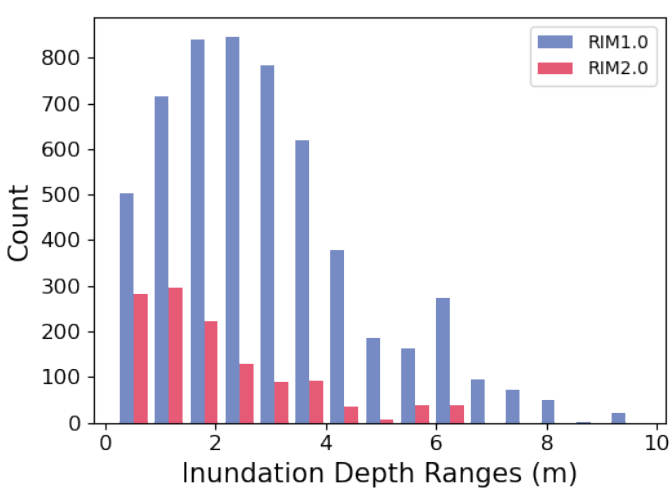

Figure 4: Inundation depth histograms for RIM1.0 and RIM2.0 for sub-basin 64

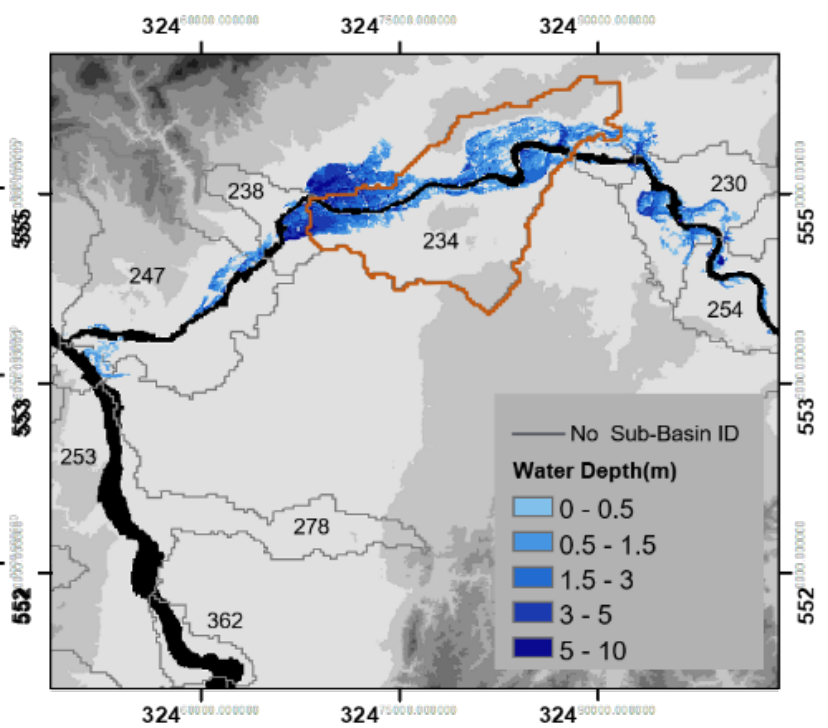



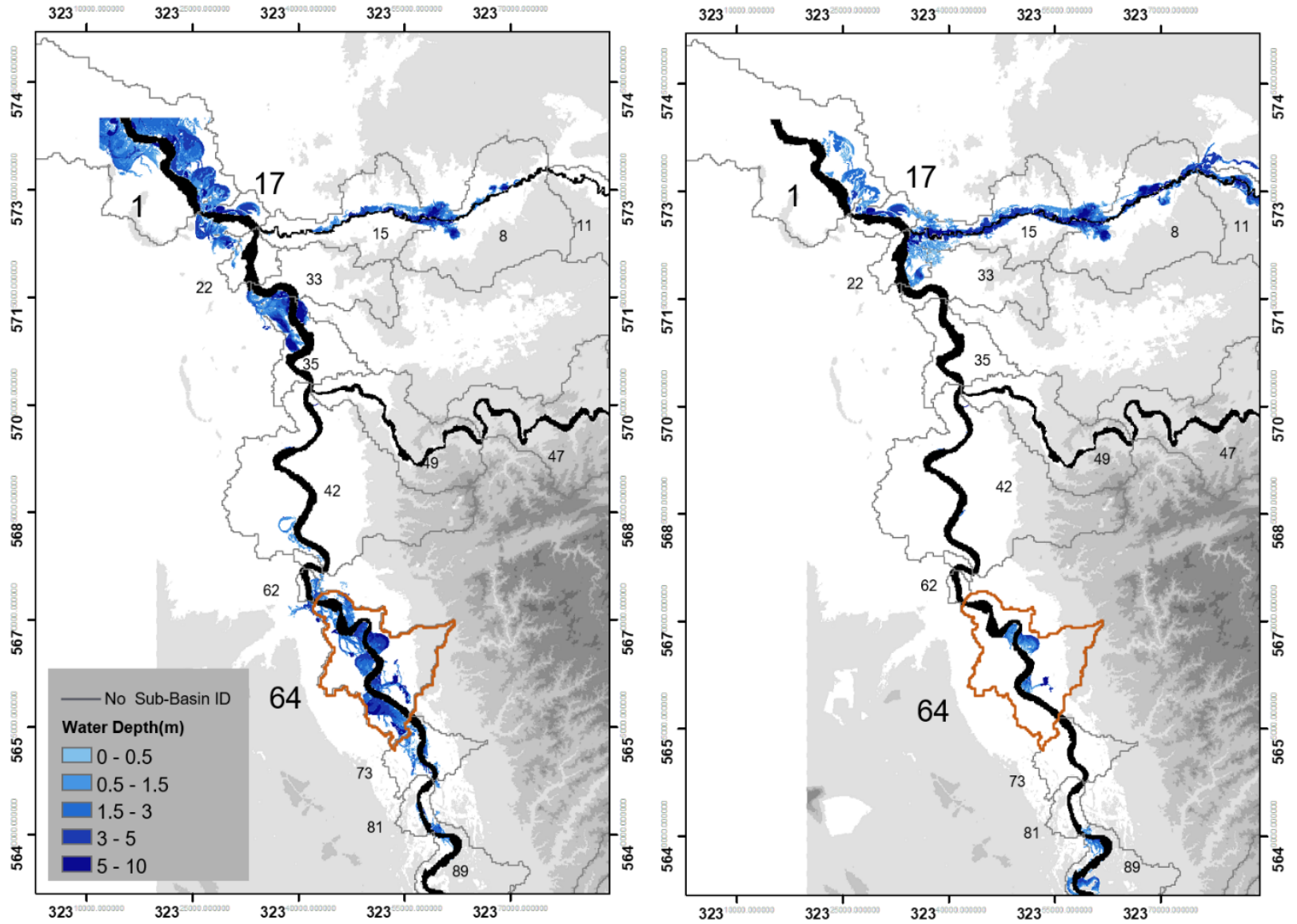

Figure 5: Inundation extent and depth for upstream and downstream sub-basins in RIM1.0 (left) and RIM2.0 (right)

\section{Conclusion}

The new version of the Regional Inundation Model RIM2.0 - was implemented and compared to the previous version. It uses continuous routing in the entire river network instead of sub-basin, piece-wise routing in the earlier version. RIM2.0 is based on the 8-point river crosssections, including the bankfull depth to represent the 1D river model domain. Hydraulic geometry relationships are used to estimate the bankfull depth in the entire river network based in the bankfull width derived from the DEM.

Calibration results of the hydrodynamic model show good model performance in terms of simulated flow hydrographs.

The overall performance of the RIM2.0 indicates the good performance of the hydraulic geometry relations to derive the bankfull area. However, deriving one relationship for the whole catchment has led to underestimation at some locations. This underestimation in the bankfull area results in an overestimation of the flooded area. Dividing the catchment based on the upstream drainage area into two parts and deriving a HG for each part separately could improve the accuracy of the estimated bankfull depths.

The routing approach changes the amount of water translated from the upstream to the downstream. While the continuous routing in RIM2.0 considers the upstream overtopping, the piece-wise routing in RIM1.0 does not.
Therefore RIM1.0 tends to overestimate inundation extent and depth at downstream sub-basins.

\section{References}

1. Arnold, J. G., Williams, J. R. and Maidment, D. R.: Continuous-time water and sediment-routing model for large basins, J. Hydraul. Eng., 121(2), 171-183, doi:10.1061/(ASCE)0733-9429(1995)121:2(171), 1995.

2. Bates, P. D., Horritt, M. S. and Fewtrell, T. J.: A simple inertial formulation of the shallow water equations for efficient two-dimensional flood inundation modelling, J. Hydrol., 387, 33-45, doi:10.1016/j.jhydrol.2010.03.027, 2010.

3. Chow, V. T.: Open Channel Hydraulics. Mcgraw-Hill Company, Erlangga : Bandung., 1959.

4. Coe, M. T., Costa, M. H. and Howard, E. A.: Simulating the surface waters of the Amazon River basin: Impacts of new river geomorphic and flow parameterizations, Hydrol. Process., 22(14), 25422553, doi:10.1002/hyp.6850, 2008.

5. Cunge, J. A., Holly, F. M. and Verwey, A. (Adri): Practical aspects of computational river hydraulics, Pitman Advanced Pub. Program. [online] Available from:

http://www.vliz.be/en/imis?module=ref\&refid=1370 06\&printversion=1\&dropIMIStitle=1 (Accessed 24 February 2019), 1980. 
6. Dino Zanobetti, H. L. et al.: Mékong Delta Mathematical Model Program Construction, J. Waterw. Harb. Coast. Eng. Div. 96, 2, 96(2), 181-199 [online] Available from: https://cedb.asce.org/CEDBsearch/record.jsp?dockey $=0017304,1970$.

7. Falter, D., Schröter, K., Dung, N. V., Vorogushyn, S., Kreibich, H., Hundecha, Y., Apel, H. and Merz, B.: Spatially coherent flood risk assessment based on long-term continuous simulation with a coupled model chain, J. Hydrol., 524, 182-193, doi:10.1016/j.jhydrol.2015.02.021, 2015.

8. Falter, D., Dung, N. V., Vorogushyn, S., Schröter, K., Hundecha, Y., Kreibich, H., Apel, H., Theisselmann, F. and Merz, B.: Continuous, large-scale simulation model for flood risk assessments: Proof-of-concept, $J$. Flood Risk Manag., 9(1), 3-21, doi:10.1111/jfr3.12105, 2016.

9. Hundecha, Y., Pahlow, M. and Schumann, A.: Modeling of daily precipitation at multiple locations using a mixture of distributions to characterize the extremes, Water Resour. Res., 45(12), doi:10.1029/2008WR007453, 2009.

10. Hunter, N. M., Horritt, M. S., Bates, P. D., Wilson, M. D. and Werner, M. G. F.: An adaptive time step solution for raster-based storage cell modelling of floodplain inundation, Adv. Water Resour., 28(9), 975-991, doi:10.1016/j.advwatres.2005.03.007, 2005.

11. International Commission for the Protection of the Rhine (ICPR): The Rhine and its Catchment: An Overview, 35 [online] Available from: https://www.iksr.org/fileadmin/user_upload/Dokume nte_de/Symposien_u. Workshops/IKSR_BRO_210x $29 \overline{7}$ ENG_26.09.13.pdf, 2013.

12. Krysanova, V., Müller-Wohlfeil, D. I. and Becker, A.: Development and test of a spatially distributed hydrological/water quality model for mesoscale watersheds, Ecol. Modell., 106(2-3), 261-289, doi:10.1016/S0304-3800(97)00204-4, 1998.

13. Metin, A. D., Dung, N. V., Schröter, K., Vorogushyn, S. and Guse, B.: The role of spatial dependence for large-scale flood risk estimation, , (December), 1-19, 2019.

14. De Paiva, R. C. D., Buarque, D. C., Collischonn, W., Bonnet, M. P., Frappart, F., Calmant, S. and Bulhões Mendes, C. A.: Large-scale hydrologic and hydrodynamic modeling of the Amazon River basin, Water Resour. Res., 49(3), 1226-1243, doi:10.1002/wrcr.20067, 2013.

15. Rawlins, C. L.: A View of the River by Luna B. Leopold, West. Am. Lit., 29(4), 386-386, doi:10.1353/wal.1995.0126, 1994. 